\title{
Geotechnical Identification and Classification of Soils as Flexible Pavement Subgrade of the Section Fongo Tongo-Melong
}

\section{François Ngapgue 1,2,3, Willy Chance Guimezap Kenou1,2,4*, Jules Hermann Keyangue Tchouata ${ }^{5}$, Vladimir Willianov Keubou Tatapzia ${ }^{3}$, Yannick Mbeuteu Mbakop ${ }^{6}$}

${ }^{1}$ Research Unit of Mechanics and Physical Systems Modeling (UR2MPS), Faculty of Sciences, University of Dschang, Dschang, Cameroon

${ }^{2}$ Laboratory of Engineering, Industrial Systems and Environment (LISIE), FOTSO Victor University Institute of Technology, University of Dschang, Dschang, Cameroon

${ }^{3}$ Laboratory of Environmental Geology, Faculty of Sciences, University of Dschang, Dschang, Cameroon

${ }^{4}$ Innovation Research Center Entrepreneurship (PRIE), Institut Universitaire de la Cote, Douala, Cameroon

${ }^{5}$ School of Geology and Mining Engineering (SGME), University of Ngaoundere, Ngaoundere, Cameroon

${ }^{6}$ Geotechnique Bâtiment et Travaux Publics (GEO TP), Douala, Cameroon

Email: *willy.kenou@myiuc.com, *willychance@gmail.com

How to cite this paper: Ngapgue, F., Kenou, W. C. G., Tchouata, J. H. K., Tatapzia, V. W. K., \& Mbakop, Y. M. (2020). Geotechnical Identification and Classification of Soils as Flexible Pavement Subgrade of the Section Fongo Tongo-Melong. Journal of Geoscience and Environment Protection, $8,183-200$.

https://doi.org/10.4236/gep.2020.811012

Received: October 5, 2020

Accepted: November 22, 2020

Published: November 25, 2020

Copyright $\odot 2020$ by author(s) and Scientific Research Publishing Inc. This work is licensed under the Creative Commons Attribution International License (CC BY 4.0).

http://creativecommons.org/licenses/by/4.0/

\section{(c) (i) Open Access}

\begin{abstract}
The present study is inscribed within the framework of the geotechnical characterization of the soils of the Santchou plain, their classification for employment as pavement subgrade, various identification tests were carried out on the samples. The results obtained showed that with a wide range of different grain sizes, the studied soils showed low content in clay grains and dominance of either sand grains or silt grains, this can be explaining how most of these soil are poorly graded. According to the USDA textural classification, the grain size distribution of these soils makes them to be classified as Silty Loam types to Sandy Loam types. Despite of their organic matter content which is less than $10 \%$, according to their respective methylene blue values, the soils studied along the section should be mainly loamy soil of medium plasticity to clayed soil, therefore showing a sensibility of its behavior to variation of water content. That last one is confirmed by the consistency parameters of these soils which show intermediate plasticity to highly plastic. Also, the bearing capacity proposed by these soils at their respective optimum dry densities is relatively small, although most of these experimental CBR values of the studied soils are more important than the ones prescribed by the AASHTO Classification system for A5, A6, and A7 types, and the French Highway Earthworks Manual Classifications system (GTR) for the corresponding $\mathrm{A} 2$ and $\mathrm{A} 3$ types.
\end{abstract}




\section{Keywords}

Soil Classification, Liquid Limit, Natural Water Content, Plasticity Index, Methylene Blue Value, Optimum Moisture Content, California Bearing Ratio

\section{Introduction}

The Melong-Fongo Tongo Roadway pavement failure is a very serious problem that causes unnecessary delay in traffic flow, distorts pavement aesthetics, breakdown of vehicle. These failures can be due to factors, such as properties of construction materials, subgrade conditions, environmental conditions, and traffic loading (Osuolale et al., 2012). The types of distresses observed, associated with the relief of the region indicate clearly that the origin of the majority of road pathologies in the studied axle is associated with subgrade ground defects (Magdi, 2014). In this work, some soils along the axle Melong-Fongo Tongo were studied in order to know their expected performance as pavement subgrade, which is an essential aspect in the design process of a flexible pavement. The natural soil, as pavement subgrade, must provide sufficient lift over the entire carriageway, and maintain this lift during the life (Mahmoud et al., 2012).

Although, the pavement subgrade can be made up of a wide variety of soil types, depending on the geographic location, geology; relief and availability of borrow material collection sites. Construction personnel must be able to identify and classify them with a reasonable degree of accuracy, according to the classification systems or guide of standards, in order to schedule earthworks and adequate earth amelioration processes if required (Surendra \& Sanjeev, 2017). Implicit in the concept that soils with similar properties can be grouped together is the assumption that correlations exist between the various soil properties. In fact, Soil classification systems are established to predict soil behavior, then expected performances, and to provide a common language for soil scientists. Properties such as grain size, mineral composition, organic matter content and soil plasticity are mainly preferred as main criteria of classification systems (Alade, 2018).

This study focused on the geotechnical identification of the soils along the Melong-Fongo-Tongo road section, their classification for use as subgrade of pavement. For this, we relied on 4 classification systems selected for their complementarity with each other.

The first two, the triangular textural USDA classification system and the unified classification system, are among the most commonly used classification systems to describe the physical and condition characteristics of the soils studied. The determination of these parameters is unavoidable, since it is according to these criteria that classification systems group soil classes, according to their behaviour or state under the effect of variations in water conditions or mechanical stress. Thus, knowing the groups or classes to which soils belong in these classification systems, it is easy to find in the literature the expected values of the index and engi- 
neering properties (Utkarsh et al., 2017). In the study of soil behavior and for the estimation of its expected performance in various fields of use, USDA and USCS classifications are generally chosen by engineers because they allow them to quickly recognize and classify soils on site using in-situ techniques (Amster, 1988).

The other two classification systems were selected because although they are commonly used in highway design and construction, they have different orientations. Thus, the AASHTO classification makes it possible to estimate the suitability of a soil as a roadbed based on physical and condition parameters (AASHTO M145-91, 2012). However, the GTR classification gives additional information giving the in-situ soil water status and subsequently prescribing the constructive solutions to be adopted according to the said in-situ status, in the roadbed development process (SETRA-LCPC, 1992). So while the AASHTO classification characterizes the performance of a soil in its optimal configuration, the GTR guide takes into account the soil condition on site and consequently the measures to be taken by professionals to work it.

\section{Investigation and Methods}

\subsection{Location of Sites and Sampling}

The road section between Melong and Fongo-Tongo, being 29 kilometers, in order to have representative samples of the area crossing by the road section, 16 sites were chosen in different parts of the road section. However; points 1 to 8 allow us, with a spacing varying between 2.5 and 5 kilometers, to cover the entire section as control samples, an in-depth study was carried out in the Locality of Fombap where 8 sites were selected between the sites 1 and 2 . In the same way, the 8 sites covering the Locality of Fombap are the sites 9 to 16, with an average distance of 500 meters between the different samples along the provincial road in the said locality.

Figure 1 and Table 1 show respectively the samples distribution along road section and the GPS coordinates of the chosen sites. These sites are far apart from 15 meters to 200 meters from the road section to avoid the embankments associated with the road section pavement. In each site, the sampling was carried out in wells deeper than $100 \mathrm{~cm}$ in order to avoid the first layer of organic soil.

\subsection{Soil Sampling}

Sampling has been performed with a shovel from the soil at a 100 to $150 \mathrm{~cm}$ depth. 14 bags of $40 \mathrm{Kg}$ each have been extracted per site selected, and mixed together to form a mixed sample on which the analysis will be performed. In addition, for the determination of the natural moisture content, samples were collected in plastic bags on the different sites. Also, in the laboratory, this mixed sample was divided into sub-sample by means of coning and quartering method (ASTM C702/C702M-18, 2018). Handling of the sample can vary, depending on the analysis and it is thus specified under the relevant headings.

Moreover; once the study sites had been selected, and the soils to be studied had been sampled, they were taken to the laboratory for a study on the physical parameters. 


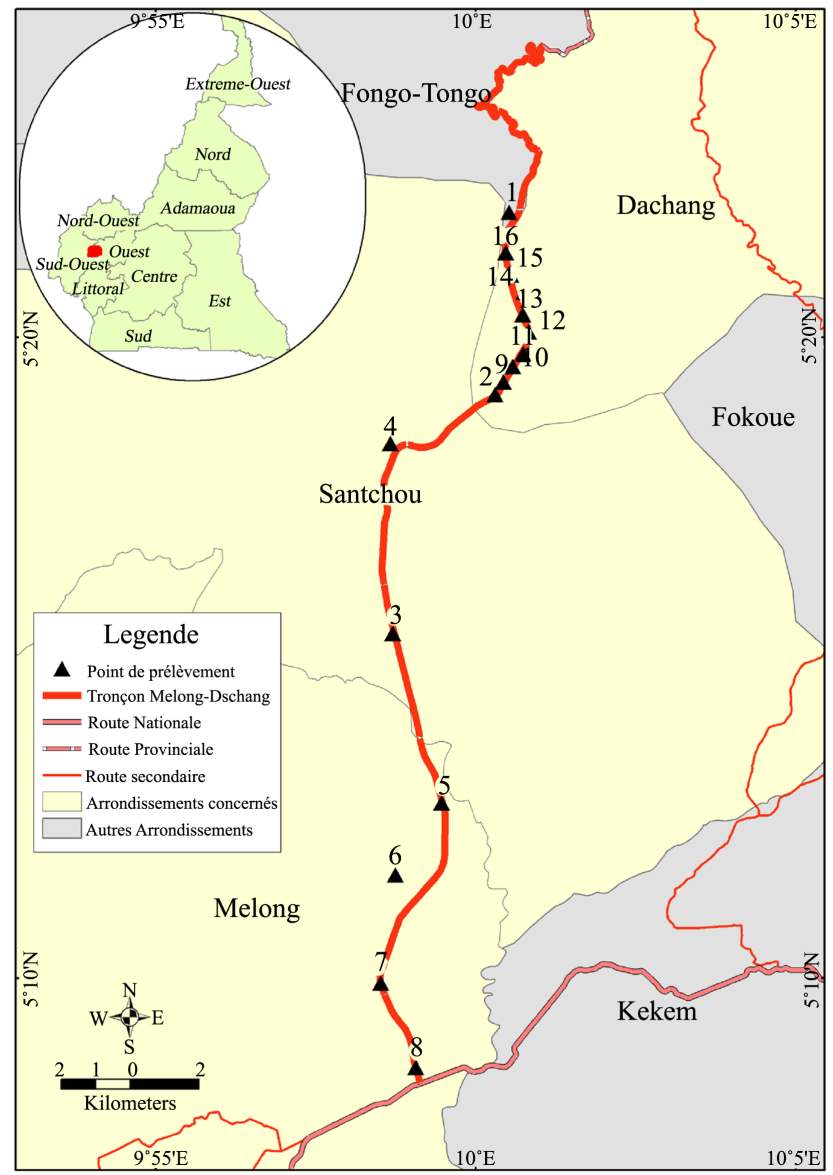

Figure 1. Sample collection points on administrative map of the Fombap District. (Sources: Data: Data collected in the field on the 27/03/2020; Basemap: Adapted from the administrative map of Cameroon, INC, 2016).

Table 1. GPS coordinates of the sampling points.

\begin{tabular}{|c|c|c|c|}
\hline Sampling point & Latitude & Longitude & Altitude \\
\hline 1 & $5^{\circ} 21^{\prime} 56.53789 " \mathrm{~N}$ & $10^{\circ} 00^{\prime} 31.31348^{\prime \prime E}$ & 720.0000 \\
\hline 2 & $5^{\circ} 19^{\prime} 06.02969^{\prime \prime} \mathrm{N}$ & $10^{\circ} 00^{\prime} 18.07261^{\prime E}$ & 721.0000 \\
\hline 3 & $5^{\circ} 15^{\prime} 22.50957^{\prime \prime} \mathrm{N}$ & $9^{\circ} 58^{\prime} 42.24409^{\prime \prime} \mathrm{E}$ & 712.0000 \\
\hline 4 & $5^{\circ} 18^{\prime} 20.37153^{\prime \prime} \mathrm{N}$ & $9^{\circ} 58^{\prime} 39.95662^{\prime \prime} \mathrm{E}$ & 733.0000 \\
\hline 5 & $5^{\circ} 12^{\prime} 43.98695 " \mathrm{~N}$ & $9^{\circ} 59^{\prime} 27.92584^{\prime \prime E}$ & 708.0000 \\
\hline 6 & $5^{\circ} 11^{\prime} 36.32356 " \mathrm{~N}$ & $9^{\circ} 58^{\prime} 44.81643 " \mathrm{E}$ & 717.0000 \\
\hline 7 & $5^{\circ} 09^{\prime} 55.10678 \mathrm{~N}$ & $9^{\circ} 58^{\prime} 30.88973 " \mathrm{E}$ & 736.0000 \\
\hline 8 & $5^{\circ} 08^{\prime} 36.25339 " \mathrm{~N}$ & $9^{\circ} 59^{\prime} 03.99394 " \mathrm{E}$ & 726.0000 \\
\hline 9 & $5^{\circ} 19^{\prime} 17.80431 " \mathrm{~N}$ & $10^{\circ} 00^{\prime} 26.05090 " \mathrm{E}$ & 730.0000 \\
\hline 10 & $5^{\circ} 19^{\prime} 32.31285^{\prime \prime} \mathrm{N}$ & $10^{\circ} 00^{\prime} 34.81341 " \mathrm{E}$ & 730.0000 \\
\hline 11 & $5^{\circ} 19^{\prime} 44.31264 " \mathrm{~N}$ & $10^{\circ} 00^{\prime} 44.41660^{\prime \prime} \mathrm{E}$ & 734.0000 \\
\hline 12 & $5^{\circ} 20^{\prime} 04.65546^{\prime \prime} \mathrm{N}$ & $10^{\circ} 00^{\prime} 49.71283^{\prime \prime E}$ & 736.0000 \\
\hline 13 & $5^{\circ} 20^{\prime} 20.94591 " \mathrm{~N}$ & $10^{\circ} 00^{\prime} 44.11928^{\prime \prime} \mathrm{E}$ & 733.0000 \\
\hline 14 & $5^{\circ} 20^{\prime} 42.04430^{\prime \prime} \mathrm{N}$ & $10^{\circ} 00^{\prime} 45.38844^{\prime \prime} \mathrm{E}$ & 736.0000 \\
\hline 15 & $5^{\circ} 20^{\prime} 58.34584 " \mathrm{~N}$ & $10^{\circ} 00^{\prime} 33.06984^{\prime \prime} \mathrm{E}$ & 722.0000 \\
\hline 16 & $5^{\circ} 21^{\prime} 18.99821 " \mathrm{~N}$ & $10^{\circ} 00^{\prime} 28.36042^{\prime \prime E}$ & 729.0000 \\
\hline
\end{tabular}




\section{Laboratory Testing}

The objectives of these tests will be to characterize the soil for use in road construction as pavement subgrade. For that, few soil classification systems have been used, these systems can be regrouped in two kinds, and the multipurpose systems represented by the triangular textural soil classification system by the United States department of agriculture (USDA Soil Textural Classification System) and the united soil classification system (USCS). Then the second kind which is oriented by the prescription in use as road subgrade, is represented respectively by the American Association of State Highway and Transportation Officials (AASHTO) and the French Road Earthworks Manual Classification (GTR, guide des terrassements routiers).

- Grain size distribution: The particles size distribution has been done with the Sieve Analysis Method and the Hydrometer Method. The Sieve analysis was used on aggregates which diameter is bigger than $80-\mu \mathrm{m}$ sieve (ASTM C136/C136M-19, 2019), while the Hydrometer Analysis method was used for fine-grained soils passing 75- $\mu \mathrm{m}$ sieve (ASTM D7928-16e1, 2016).

- Consistency Parameters: In the present work, the liquidity limits were determined by the penetration cone method, while the plasticity limit was determined by the roll method (ASTM D4318-17e1, 2017).

- Natural water content: The test procedure of the "Oven dry method" was used to find the water content of soils. It consists to dry specimens in the oven at a temperature of $105^{\circ} \mathrm{C}$ for 24 hours, then we can compare the weight before and after the drying session (ASTM D2216-19, 2019).

- Organic Matter Content: The organic content of materials studied was determined by the use of sulfochromic dosage method (NF ISO 14235, 1998).

- Methylene blue test: This test is based on the phenomenon of adsorption peculiar to clays. It consists of measuring, per $100 \mathrm{~g}$ of material, the quantity of methylene blue necessary to cover the outer and inner surface of the particles. The methylene blue adsorption method tests were carried out (ASTM C837-09, 2019).

- Proctor Test: To determine the amount of compaction required by the soil and above all the associated optimum water content, the compaction tests were conducted in the laboratory via the modified Proctor test (ASTM D1557-12e1, 2012). Through these tests, the water content-dry density curves were plotted. These curves, which are specific to each material, give at their peaks respectively the maximum dry densities and the optimum Moisture content as easting and northing values.

- California Bearing Ratio test: The California bearing ratio is the ratio of force per unit area required by a circular plunger of $50 \mathrm{~mm}$ diameter at the rate of $1.25 \mathrm{~mm}$ per minute, to penetrate into a soil mass conditioned according to his optimum moisture content (ASTM D1883-16, 2016). In this study, the compacted specimens were soaked in water for 96 hours before subjected to the punching in the CBR testing machine. 
- Analysis of Results: The main statistical tools, mean and standard deviation, will be used on the results of the tests to which the 16 samples were subjected in order to estimate the probable characteristics and performance of the soils in the study area. Then, variation ratio, or coefficient of variation, which is a relative measure of the dispersion of the data around the mean, is used to compare the degree of variation from one sample to another, even if the means are different. The coefficient of variation is calculated as the ratio of the standard deviation to the mean and is expressed as a percentage.

- Soil Classification: Mainly based on the grain size analysis and the Atterberg limits, the multipurpose soils classifications systems help engineers to describe their texture (USDA), and their consistency (USCS). In fact, the USDA textural classification System is based on the grain size distribution (USDA, 2012), when the USCS refers simultaneously to the grain size distribution, the organic matter content and the consistency parameters represented by the Atterberg limits (ASTM D2487, 2006). The AASHTO and the French Road Earthworks Manual Classification systems propose prescriptions and conditions to use the studied soils as highway materials based in addition to the grain size analysis and the Atterberg limits, the California bearing ratio, and the methylene blue value specially for the French Road Earthworks Manual Classification system (SETRA-LCPC, 1992).

\section{Results and Discussions}

\subsection{Gradation Curves}

The gradations curves of the studied soil have been plotted by means of the grain size analysis and the hydrometer analysis. Different types of shape of curves were obtained, describing the corresponding grain size distribution of the relevant soils. In this study, the gradation curves obtained have been classified into 4 groups based on their shapes, Figures 2-4 show the gradation curves of the 16 sites studied. Figure 2 shows the gradation curves of the sites 1, 3, 7 and 12.

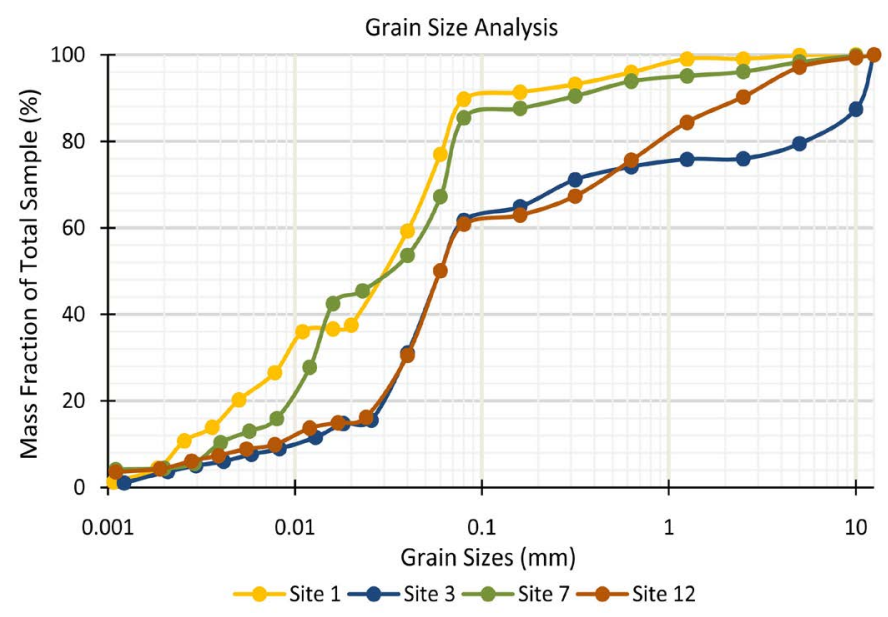

Figure 2. Grain size distribution curves of the Sites 1, 3, 7 and 12. 


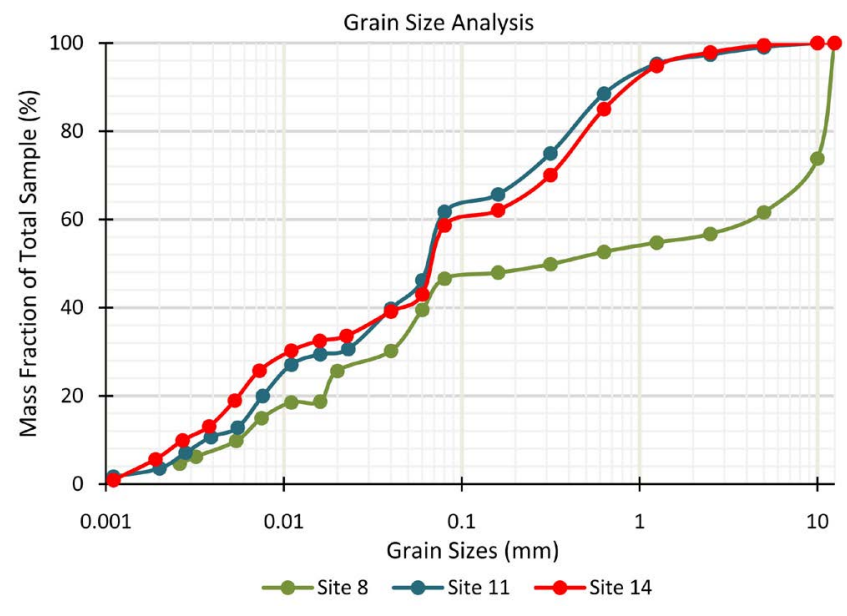

Figure 3. Grain size distribution curves of the Sites 8, 11 and 14.

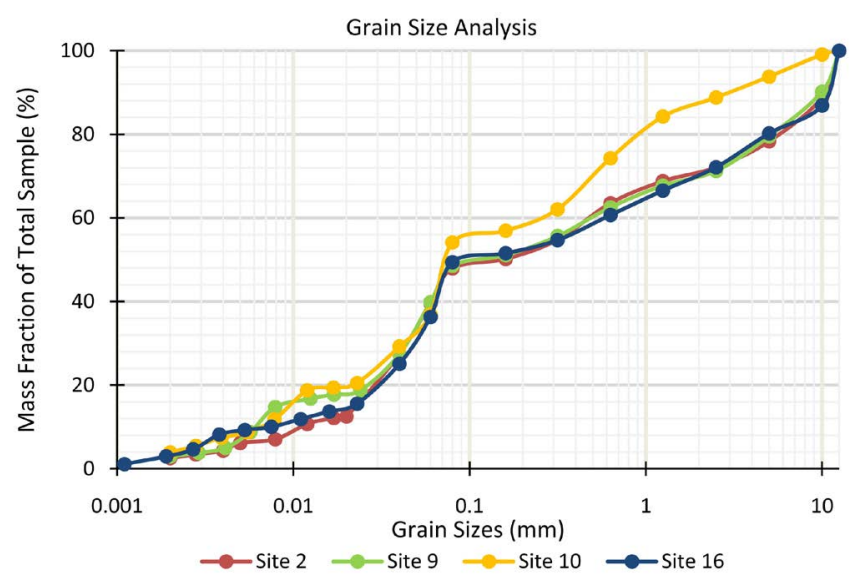

Figure 4. Grain size distribution curves for the Sites 2, 9, 10 and 16.

The curves show that, for site 1 and 7, 95\% of particles are passing the sieve $0.8 \mathrm{~mm}$ corresponding to the lower limit of sandy particles. At the same time, the upper limit of silty particles and more than $80 \%$ are passing the sieve $0.080 \mathrm{~mm}$, the sieve besides the lower limit of silty particles. Then, although the samples 3 and 12 show curves of a similar shape, particles passing the sieve $0.8 \mathrm{~mm}$ are near $76 \%$ and those passing the sieve $0.080 \mathrm{~mm}$ are near $60 \%$. The shape of the curves in Figure 2 shows a very poor gradation characteristic of materials, in fact, the variations of the slope of the curves are relevant depending on the grain size range. The slopes of the 4 curves increase significantly when the size of particles are between 0.02 to $0.06 \mathrm{~mm}$, an interval remaining to the range of silty particles. In conclusion, although the samples 3 and 12 show bigger proportions of sand and gravel than the samples 1 and 7 , all the curves show a predominance of silty particles for an approximated percentage of $50 \%$, then comes the sandy particles for a percentage around $45 \%$. These soils are classified as fine-grained soils in the USCS classification, with their respective sand content far more superior than their gravel content, except in the soil 3 where the gravel content reaches 23\%. Figure 3 shows the gradation curves of the sites 8,11 and 14 . 
The curves shown in Figure 3 are more distributed than the ones shown in Figure 2, similar behaviors of their slopes between 0.02 to $0.06 \mathrm{~mm}$ grain size are observed. These samples still show a relevant content of silty particles with a percentage near $40 \%$ for the soils 11 and 14 . But, according to USCS, the soil 8 shows a percentage of $44 \%$ passing the sieve 200 , classify it as a coarse-grained soil. While the soils 11 and 14 , with more of $52 \%$ of particles passing the sieve 200, are classified around the fine-grained soils. The samples 11 and 14 have a minor content of gravel with a maximum of $3 \%$, but the sample 8 shows sizable proportions of gravel reaching 38\%. Figure 4 shows the gradation curves of the samples 2, 9, 10 and 16. The grain size distribution curves of sites 4, 5, 6, 13 and 15 are presented on Figure 5.

According to these figures, with less than $48 \%$ of particles passing the sieve 200, these soils are classified as coarse-grained soils, regarding the USCS chart. For all these samples, the clayed particles corresponding to the fraction smaller than $0.002 \mathrm{~mm}$, represent less than $10 \%$ by weight, while the following content of silty particles is from $37 \%$ to $65 \%$, the sandy particles are from $40 \%$ to $55 \%$. But the gravel aggregate which represents $10 \%$ for sample 10, reaches the relevant proportion of $25 \%$ for the samples 2,9 and 16 .

As the precedent one, these soils are in conclusion mainly composed of sand and silt. The gradation curves were more distributed for the samples 4, 5, 6, 13 (Figure 5) than for the samples 2, 9, and 16 (Figure 4). While samples 4, 6 and 13 and 15 are coarse-grained soils, the soil 15 offer less than $12 \%$ of gravel when the others show a relevant gravel content with more than $20 \%$, also with the sample 5 although it is the only fine-grained soil in the group according to the USCS.

The general observation of the 16 soil's gradation curves shows that all these soils have low clay content, globally under $10 \%$. Their respective sand and silt content are relevant, mainly between 30 to 50 percent each. Then, some soil can show non-negligible gravel content specially the soil 8 with $38 \%$ of gravel, and

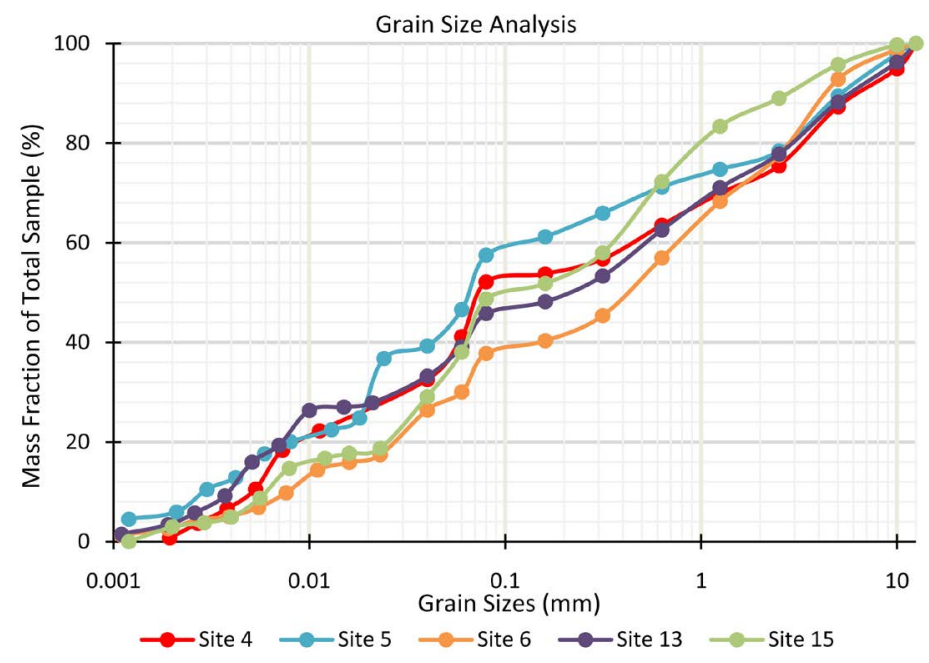

Figure 5. Grain size distribution curves for the Sites 4, 5, 6, 13 and 15. 
the soil 2, 9 and 16 with a gravel content which reaches $20 \%$ each. According to the USCS Chart, the soils 5, 11, 1, 3, 7, 12, and 13 are fine-grained soils, while the others were classified as coarse-grained soils with one gravel represented by the sample 8, and eight sands represented by the soils 10,2, 9, 10, 4, 6 and 15. But according to the AASTHO chart, all the studied soils remain to the Silt-Clays materials group, with more than $35 \%$ of their particles passing the sieve 200 . The detailed results of the grain size analysis such as the gradation coefficients, and the particle size distribution according to the USDA classification system are presented in the next paragraph.

\subsection{Grain Size Analysis}

As a confirmation of the shape of the gradation curves, the results in Table 2 show that the sixteen soils samples have small clay content which reaches $8 \%$ for the sample 5, while their corresponding sand and silt content are between $22 \%$ to $58 \%$ for sand and $37 \%$ to $72 \%$ for silt. According to the results, the average content of the soil across the axle Melong-Dschang are $44.5 \%$ of sand, $50.6 \%$ of silt and $4.8 \%$ of sand; with relative variation ratio of $18 \%, 15 \%$ and

Table 2. Grain size distribution.

\begin{tabular}{|c|c|c|c|c|c|}
\hline \multirow{2}{*}{ Soil Sample } & \multicolumn{3}{|c|}{ Particle Size Distribution according to USDA } & \multicolumn{2}{|c|}{ Soil Gradation } \\
\hline & Sand & Silt & Clay & $\mathrm{Cu}$ & $\mathrm{Cc}$ \\
\hline $\mathrm{P} 1$ & 22.22 & 72.73 & 5.05 & 16 & 0.76 \\
\hline $\mathrm{P} 2$ & 43.66 & 52.77 & 3.56 & 413 & 3.71 \\
\hline P3 & 31.40 & 63.98 & 4.62 & 8 & 2.03 \\
\hline $\mathrm{P} 4$ & 41.26 & 57.38 & 1.37 & 87 & 0.38 \\
\hline P5 & 37.66 & 54.68 & 7.66 & 43 & 1.1 \\
\hline P6 & 58.11 & 37.84 & 4.05 & 99 & 0.63 \\
\hline P7 & 29.17 & 66.23 & 4.60 & 13 & 0.89 \\
\hline P8 & 26.79 & 65.71 & 7.50 & 833 & 0.07 \\
\hline P9 & 41.43 & 54.29 & 4.29 & 83 & 0.68 \\
\hline $\mathrm{P} 10$ & 54.02 & 41.38 & 4.60 & 40 & 1.07 \\
\hline P11 & 50.52 & 45.77 & 3.71 & 21 & 1.48 \\
\hline $\mathrm{P} 12$ & 41.24 & 53.79 & 4.97 & 9 & 2.54 \\
\hline $\mathrm{P} 13$ & 46.67 & 48.67 & 4.67 & 133 & 0.39 \\
\hline P14 & 54.64 & 39.48 & 5.88 & 191 & 0.08 \\
\hline $\mathrm{P} 15$ & 55.17 & 41.38 & 3.45 & 58 & 0.84 \\
\hline P16 & 45.71 & 50.00 & 4.29 & 79 & 0.54 \\
\hline Average & 44.54 & 50.67 & 4.80 & 146.00 & 0.86 \\
\hline Ecart-Type & 7.90 & 7.47 & 0.79 & 146.40 & 0.51 \\
\hline Variation Ratio & $18 \%$ & $15 \%$ & $17 \%$ & $100 \%$ & $59 \%$ \\
\hline
\end{tabular}

Where $\mathrm{Cu}$ and $\mathrm{Cc}$ are respectively uniformity and the gradation coefficients. 
17\%. According to the USDA soil textural classification, the soil studied are loamy, following their respective sand and silt content, they can be silty loam as P1 to P5, P7 to P9, P12 and P16; or sandy loam as P6, P10, P11 and P13 to P15. Regarding the related grain size distribution showed by the studied soils, the soils across this road section can be characterized as silt loam, or sandy loam for the samples when the sand content increase across $45 \%$. The French road earthwork manual classified the studied soils as fine grained soil of the group A. The subcategories can be determined with the analysis of the consistency parameters.

Regarding the uniformity and gradation coefficients in Table 2, we notice that although most of the corresponding Coefficients of Uniformity $(\mathrm{Cu})$ are far above six, meaning that the soils of this area offer a wide range of different sizes, the following Coefficient of Curvature (Cc) observes are from 0.4 to 3.71. Regarding that, we observe only six soils on sixteen, the samples $2,3,5,10,11$ and 12 are well graded when the other are poorly graded, despite of their respective Coefficients of Uniformity $(\mathrm{Cu})$.

\subsection{Organic Matter Content}

Through the results of Table 4, the Organic Matter contents are quite low and vary between $0.58 \%$ for P6, and $9.69 \%$ for P4. All samples have content less than $10 \%$. Hence, average organic matter content is $7 \%$ with a variation ratio of $13 \%$. Regarding the grain size analysis associated with the corresponding organic matter content, the studied soil can be considered in the USCS chart, as inorganic fine-grained soils.

\subsection{Atterberg Limits}

Table 3 shows that the samples plasticity limits are from $36 \%$ to $72 \%$, the average plasticity limit is $51.8 \%$ with a variation ratio of $15 \%$. Whereas the liquid limits are from $51 \%$ to $81 \%$, the average of $67.8 \%$ with a variation ratio of $12 \%$. The different consistency index is above 1, respectively from 1.93 to 7.69 , representative of soils in the solid state when they are at their natural water content. Also, the corresponding plasticity index of these soils is in the range 6.15 to 26.85 , with an average value of 16.1 . The soil 14 have a plastic index lower than 7 , it is the only slightly plastic soil above the sixteen. While, with a plasticity index between 7 and 17, the soils $1,5,8,12$, and 15 show intermediate plasticity, and the 10 other remaining soils are highly plastic, their corresponding plastic index is above 17. Regarding their respective liquid limits superior to $50 \%$, and their plasticity index 27 , the fine particles of the different studied soils are, according to the USCS chart, classified as silty soils of high plasticity (MH). According to the AASHTO chart, our studied silt-clay materials, which show liquid limits above $40 \%$, are classified in the A-5 group for samples $1,15,14$ and 12 with respective plasticity index below 10, and the A-7 group for the rest of studied samples with the subgroup A7-5 and A7-6 depending on the difference between the plasticity index and the liquid limit. The studied samples, 
Table 3. Consistency parameters.

\begin{tabular}{ccccc}
\hline \multirow{2}{*}{ Soil Sample } & \multicolumn{2}{c}{ Atterberg Limits } & \multicolumn{2}{c}{ Consistency Parameters } \\
\cline { 2 - 5 } & Wp \% & WL \% & Ip & Ic \\
\hline P1 & 63.69 & 70.90 & 7.21 & 5.50 \\
P2 & 51.66 & 72.30 & 20.64 & 2.65 \\
P3 & 40.74 & 57.90 & 17.16 & 2.44 \\
P4 & 54.57 & 73.20 & 18.63 & 2.92 \\
P5 & 47.72 & 58.10 & 10.38 & 3.54 \\
P6 & 53.94 & 77.90 & 23.96 & 2.65 \\
P7 & 60.86 & 81.70 & 20.84 & 2.18 \\
P8 & 48.72 & 61.80 & 13.08 & 2.95 \\
P9 & 36.43 & 53.40 & 16.97 & 1.93 \\
P10 & 53.97 & 71.42 & 17.45 & 2.68 \\
P11 & 47.32 & 63.40 & 16.08 & 2.60 \\
P12 & 71.56 & 79.20 & 7.64 & 7.94 \\
P13 & 44.15 & 71.00 & 26.85 & 1.86 \\
P14 & 60.25 & 66.40 & 6.15 & 7.69 \\
P15 & 43.12 & 51.50 & 8.38 & 4.11 \\
P16 & 51.18 & 77.80 & 26.62 & 2.18 \\
Average & 51.76 & 67.76 & 16.01 & 3.61 \\
Ecart-Type & 7.92 & 8.46 & 5.75 & $39 \%$ \\
Variation Ratio & $15 \%$ & $12 \%$ & $36 \%$ & 1.78 \\
\hline
\end{tabular}

Where $\mathrm{Wp}$ is the plasticity limit; Ip is plasticity index; Ip is the plasticity index; Ip is the plasticity index.

which are classified by the USDA triangular textural classification as silty loamy and sandy loamy soils are supposed to be slightly plastic, to plastic. Regarding their respective plasticity index, these soils are recognized by the French road earthworks manual as silts with high plasticity for samples 13 and 16, soils remaining in the subgroup A-3 which correspond to clayed soil with high plasticity, while most of the other remaining in the subgroups A-2 and A-1 corresponding plasticity index values between 12 to 25 and 0 to 12 for samples $1,5,12$, 14 and 15. Although in this last range of index plasticity values, that is from 0 to 12 , the methylene blue value is more adapted as identification criteria. Table 4 shows composition of the studied soil through the content in water, represented by the natural water content, then the content in clay minerals, represented by the methylene blue values, and finally the organic matter content.

\subsection{Methylene Blue Value}

It emerges from Table 4 that the VBS values are greater than 2.5 , which indicates that all the sediments are sensitive to water. Among the samples studied, the highest values are those of points $\mathrm{P} 4$, and $\mathrm{P} 14$ which are very clayey soils 
Table 4. Soil components.

\begin{tabular}{|c|c|c|c|}
\hline \multirow{2}{*}{ Soil Sample } & Water Content & Clay Minerals Content & Organic Matter Content \\
\hline & Wnat $\%$ & VBS & OM\% \\
\hline $\mathrm{P} 1$ & 31.25 & 4 & 7.86 \\
\hline $\mathrm{P} 2$ & 17.67 & 7 & 7.88 \\
\hline P3 & 16.04 & 6 & 3.10 \\
\hline $\mathrm{P} 4$ & 18.79 & 9 & 9.69 \\
\hline P5 & 21.36 & 6 & 0.91 \\
\hline P6 & 14.30 & 5 & 0.58 \\
\hline P7 & 36.20 & 7 & 1.00 \\
\hline P8 & 23.20 & 3 & 7.28 \\
\hline P9 & 20.58 & 6 & 7.33 \\
\hline $\mathrm{P} 10$ & 24.65 & 8 & 7.55 \\
\hline P11 & 21.65 & 6 & 2.94 \\
\hline $\mathrm{P} 12$ & 18.56 & 3 & 7.00 \\
\hline $\mathrm{P} 13$ & 20.95 & 6 & 7.21 \\
\hline P14 & 19.09 & 9 & 7.42 \\
\hline $\mathrm{P} 15$ & 17.09 & 7 & 7.86 \\
\hline P16 & 19.68 & 5 & 8.42 \\
\hline Average & 22.17 & 6.05 & 5.88 \\
\hline Ecart-Type & 3.51 & 1.40 & 1.77 \\
\hline Variation Ratio & $16 \%$ & $23 \%$ & $30 \%$ \\
\hline
\end{tabular}

In this table, Wnat is the natural water content; VBS is the methylene blue value; OM is the organic matter content.

with blue values greater than 8 ; then 6 soils are recognized as silty soil of average plasticity with blue values between 2.5 and 6; while the remaining 8 soils are classified as clayey with blue values between 6 and 8 . The average methylene blue value over the 16 soils is 6.1 with a coefficient of variation of $21 \%$ stipulating that the soils studied along the section will be mainly loamy of medium plasticity or clayed soil. According to the French road earthworks manual, all the studied samples have their methylene blue value superior to 2.5 , values excluding their appartenance to the A1 subgroup, the only subgroup of fine-grained soils where the methylene blue value is the most adequate criteria of classification. Regarding the different values, the samples remain to the subgroup A-2, and the subgroups A-3 to A-4 corresponding to clayed soils of high plasticity for site 4 and 14. The soil component is shown in Table 4.

\subsection{Compaction Parameters}

The optimum water content of the different studied soils is from $16 \%$ to $32 \%$, when 10 soils under 16 have their optimum water content in the range $18 \%$ - 
$22 \%$. The average of optimum moisture of the 16 soils is $20.87 \%$ with a variation ratio of $16 \%$. As well as, the USCS prescribed range value for the optimum bulk density according to the groups in which the soils remain to. To add, the still prescribed values for the Silty Sand soils (SM) are 1.77 to 2.01 (Surendra and Sanjeev, 2017), the Maximum Dry Densities of the soil concerned (P6, P10, P11, $\mathrm{P} 14, \mathrm{P} 15)$ are for some (P6, P10, P14) in the range while the others (P11 and P15) are below. The prescribed values for the Sandy Elastic Silt soils ( $\mathrm{MH})$ are 1.12 to 1.52 (Thomas, 2012), except the soil P7 which is in this range, all the remaining soils are above the upper limit. Therefore, the corresponding dry densities show more uniforms values with an average of 1.7 associated with a variation ratio of $4 \%$. Hence, this uniformity can be explained by the one showed by the specific density values and similar type of grain size distribution. The optimum moisture can also be affected by the organic matter content (Masi et al., 2020), the methylene blue value, and the clay proportion in grain size distribution, in fact, these parameters influence the water retention when their values increase. In the French Road Earthworks Manual, the optimum water content is compared with the natural water content to describe the hydric state of the corresponding soils, the determination on the natural water content guides the engineers to select the process of preparation of soil before earthmoving activities.

\subsection{Natural Water Content}

The natural water content obtained has been reported in Table 4 . These results are between $14.30 \%$ and $36.20 \%$, with an average of $22.2 \%$ and a standard deviation of $3.5 \%$. Samples were taken from the different sites in May, at the start of the rainy season, and during a two-week campaign, so it is inefficient to analyze the differences between the natural water contents obtained. In fact, these values can also be influenced by various factors such as the depth of the well, the position of the sites vis-à-vis the watersheds, and the nature of the soils which have a water retention capacity depending on the content in fine elements and in Organic Matter (Ben Abdelghani et al., 2014). The relative natural water content values of the studied soil have been compared to their optimum moisture content, for the determination of the hydric state according to the French Road Earthworks Manual. After comparison, we notice that if most of these soils have average water content, it means that the natural water content of the corresponding soils in situ is near their corresponding optimum water content. But some samples show, natural water content above more than $20 \%$ (site 1, 9 and 11 ) or $40 \%$ (site 10) of their relative values of the optimum moisture content, these soils are considered to be respectively wet or muddy. Then four other studied soils, shows natural water content respectively below $90 \%$ (sites 6, 15 and 16) to 70\% (site

7) of their respective optimum moisture, corresponding to dry to very dry soils.

\subsection{California Bearing Ratio}

The subgrade must be able to support loads transmitted from the pavement structure. This load-bearing capacity is often affected by degree of compaction, 
Table 5. Compaction parameters and bearing capacity.

\begin{tabular}{cccc}
\hline \multirow{2}{*}{ Soil Sample } & \multicolumn{2}{c}{ Compaction Parameters } & Bearing Capacity \\
\cline { 2 - 4 } P1 & Wopm\% & xdMax & Soaked CBR \\
\hline P2 & 19.50 & 1.58 & 3 \\
P3 & 19.50 & 1.59 & 24 \\
P4 & 17.90 & 1.75 & 22 \\
P5 & 17.80 & 1.72 & 7 \\
P6 & 19.50 & 1.60 & 35 \\
P7 & 18.20 & 1.81 & 16 \\
P8 & 31.90 & 1.43 & 6 \\
P9 & 25.70 & 1.61 & 12 \\
P10 & 18.40 & 1.76 & 11 \\
P11 & 16.00 & 1.77 & 8 \\
P12 & 19.10 & 1.70 & 9 \\
P13 & 17.40 & 1.74 & 14 \\
P14 & 20.40 & 1.74 & 13 \\
P15 & 17.70 & 1.79 & 18 \\
P16 & 20.50 & 1.72 & 16 \\
Average & 21.60 & 1.72 & 3 \\
Ecart-Type & 20.87 & 1.70 & 12 \\
Variation Ratio & 3.32 & 0.07 & $4 \%$ \\
\hline
\end{tabular}

With Wopm\%: Optimum Moisture Content, đdMax: Maximun Dry Density.

moisture content, and soil type (Schaefer et al., 2008). If the soaked CBR value of the studied soil (Table 5) are between 3\% for P1 and 35\% for P5, most of the value recorded after the tests are from $8 \%$ to $16 \%$. The average of CBR value obtained is $12 \%$ with a standard deviation of $3 \%$. If we try to compare the experimental data with the value preconized by the French Road Earthworks Manual, we are going to see that, for the soils P2, P3, P5, P8, experimental values are more important than the one preconized by the subgroups A2m when $\mathrm{P} 4$ and $\mathrm{P} 14$ are in the preconize range, which is $5 \%$ to $15 \%$. Moreover, If the experimental value of the CBR for the point P1 (3\%) is in the preconized range of the A2h subgroup which is $2 \%$ to $5 \%$, the CBR value of the 2 other soils P9 and P11 are more important than the upper limit. The point P12 and P13 respectively classified in the subgroup A1m and A3m have experimental values more than convenient when we compare it to the prescribed ones. In fact, the P12 soil CBR value is in the range of the $\mathrm{A} 1 \mathrm{~m}$, which is $8 \%$ to $25 \%$, and the $\mathrm{P} 13$ soil CBR value is far more important than the upper limit of the range prescribed. Regarding the USDA triangular textural chart, the expected value of CBR for sandy loam and silt loam soils, should be from 5 to 40, range where all the samples CBR values remain to, except the sample 1 with a poor CBR of 3 . 


\subsection{Soil Classification}

The different classifications of the soils studies are presented on Table 6. According the AASHTO, the soils studied are classified, as Silty to Clayed materials, the different groups in which they belong are the groups A-5 for P1, P14, P15 and the group A-7 for the remaining soils. ASTM D3282-09 Standard Practice rates these different groups to be fair to poor for a use as road subgrade for Classification of Soils and Soil-Aggregate Mixtures for Highway Construction Purposes. In spite of, the subgroups of the soils belonging to the group A7 are A7-6 for sites 3, 6, 9, and 13 when the others are A7-5, these shows the plasticity

Table 6. Soil Classification of samples studied.

\begin{tabular}{|c|c|c|c|c|}
\hline \multirow{2}{*}{$\begin{array}{c}\text { Soil } \\
\text { Sample }\end{array}$} & \multicolumn{2}{|c|}{ Multipurpose Classification Systems } & \multicolumn{2}{|c|}{$\begin{array}{c}\text { Earthworks and Pavement } \\
\text { Design oriented } \\
\text { Classification Systems }\end{array}$} \\
\hline & $\begin{array}{c}\text { USDA Soil } \\
\text { Textural } \\
\text { Classification }\end{array}$ & USCS & AASHTO & $\begin{array}{c}\text { French Road } \\
\text { Earthworks } \\
\text { Manual (GTR) }\end{array}$ \\
\hline P1 & Silty Loam & Sandy Elastic Silt (MH) & A-5 & $\mathrm{A} 2 \mathrm{~h}$ \\
\hline $\mathrm{P} 2$ & Silty Loam & Silty Sand With Gravel (SM) & A-7-5 & $\mathrm{A} 2 \mathrm{~m}$ \\
\hline P3 & Silty Loam & Sandy Elastic Silt $(\mathrm{MH})$ & A-7-6 & $\mathrm{A} 2 \mathrm{~m}$ \\
\hline $\mathrm{P} 4$ & Silty Loam & Silty Sand (SM) & A-7-5 & $\mathrm{A} 2 \mathrm{~m}$ \\
\hline P5 & Silty Loam & Sandy Elastic Silt (MH) & A-7-5 & $\mathrm{A} 2 \mathrm{~m}$ \\
\hline P6 & Sandy Loam & Silty Sand (SM) & A-7-6 & A $2 s$ \\
\hline P7 & Silty Loam & Sandy Elastic Silt (MH) & A-7-5 & A2 ts \\
\hline P8 & Silty Loam & Silty Gravel with Sand (GM) & A-7-5 & $\mathrm{A} 2 \mathrm{~m}$ \\
\hline P9 & Silty Loam & Silty Sand (SM) & A-7-6 & $\mathrm{A} 2 \mathrm{~h}$ \\
\hline $\mathrm{P} 10$ & Sandy Loam & Silty Sand (SM) & A-7-5 & A2 th \\
\hline P11 & Sandy Loam & Sandy Elastic Silt (MH) & A-7-5 & $\mathrm{A} 2 \mathrm{~h}$ \\
\hline $\mathrm{P} 12$ & Silty Loam & Sandy Elastic Silt (MH) & A-5 & A1 m \\
\hline $\mathrm{P} 13$ & Sandy Loam & Sandy Elastic Silt (MH) & A-7-6 & A $3 \mathrm{~m}$ \\
\hline $\mathrm{P} 14$ & Sandy Loam & Silty Sand (SM) & A-5 & $\mathrm{A} 2 \mathrm{~m}$ \\
\hline P15 & Sandy Loam & Silty Sand (SM) & A-5 & A2 s \\
\hline P16 & Silty Loam & Silty Sand With Gravel (SM) & A-7-6 & $\mathrm{A} 3 \mathrm{~s}$ \\
\hline $\begin{array}{c}\text { Parameter of } \\
\text { Selection Criteria } 1\end{array}$ & $\begin{array}{c}\text { Grain Size } \\
\text { Analysis }\end{array}$ & Grain Size Analysis & $\begin{array}{l}\text { Grain Size } \\
\text { Analysis }\end{array}$ & $\begin{array}{l}\text { Grain Size } \\
\text { Analysis }\end{array}$ \\
\hline $\begin{array}{c}\text { Parameter of } \\
\text { Selection Criteria } 2\end{array}$ & - & Consistency Parameters & $\begin{array}{l}\text { Consistency } \\
\text { Parameters }\end{array}$ & $\begin{array}{l}\text { Consistency } \\
\text { Parameters }\end{array}$ \\
\hline $\begin{array}{c}\text { Parameter of } \\
\text { Selection Criteria } 3\end{array}$ & - & - & - & $\begin{array}{l}\text { Mechanical } \\
\text { parameters }\end{array}$ \\
\hline $\begin{array}{c}\text { Parameter of } \\
\text { Selection Criteria } 4\end{array}$ & - & - & - & $\begin{array}{c}\text { Soil } \\
\text { composition }\end{array}$ \\
\hline
\end{tabular}


of the different soils through a relation between its relative liquid limits and plasticity index. The French Road Earthworks Manual (GTR) classified the studied soil in the category of fine-grained soil. In this classification system, the subgroups describe the consistency parameter or the water sensibility of the soils through their respective plasticity index and methylene blue value. According to their respective methylene blue values, 14 soils on 16 are belonging to the A2 group, the remaining soils $\mathrm{P} 12$ and P16 are classified respectively in the A1 and A3 groups. The last parameters of the French Road Earthworks Manual Classification (GTR) are the moisture state, the soil for compaction, which is expressed by the comparison between respective natural water content to optimum moisture content. This comparison shows that four soils on 16 are wet to very wet (P1, P9, P10, P11), four are dry to very dry (P6, P7, P15, P16) and the remaining eight have intermediate moisture content.

\section{Conclusion}

The objectives of the geotechnical studies will be to characterize the soils across the axe Melong-Fongo Tongo for use in road construction as pavement subgrade. The organic matter contents show that these soils are inorganic. The silt and the sand fraction are the mainly represented after the grain size analysis, and the corresponding consistency parameters describe soil with high liquid limit but low to average plasticity index, properties of silty or sandy loamy soil according to the triangular textural USDA classification and silty sand or sandy silt according to USCS classification system. These soils are sticky and show average to high plasticity. Referring to the earthworks purpose classification systems, the results show us that these soils remain to the group A-5 and A-7 according to AASHTO and the group A2 and A3 according to the French Road Earthworks Manual. The California Bearing Ratio values of these soils foresee fair to poor expected performance as pavement subgrade, even at their optimum compaction. According to the soil classes or type they remain, the performance for seepage control expected are high compressibility, poor workability as construction materials, and semi-pervious to impervious characteristics when compacted. As embankments, instead of these soils, have good ability to take plastic deformation without shearing, they offer fair to poor shear strength or stability. These performances can be upgraded with the employment of lime stabilization process in order to increase the plasticity index and the California Bearing Ratio values.

\section{Acknowledgements}

The authors would like to thank Institut Universitaire de la Côte (IUC, Douala-Cameroon) and its Research Center for Innovation and Entrepreneurship Teams, Geotechnique Bâtiment et Travaux Publics (GEO TP, Douala-Cameroon) and its laboratory technicians, for their assistance in the studies that led to the completion of this work. 


\section{Conflicts of Interest}

The authors declare no conflicts of interest regarding the publication of this paper.

\section{References}

AASHTO M145-91 (2012). Classification of Soils and Soil-Aggregate Mixtures for Highway Construction Purposes. Washington DC: American Association of State Highway and Transportation Officials.

Alade, S. M. (2018). Correlation of Unified and AASHTO Soil Classification Systems for Soils Classification. Journal of Earth Sciences and Geotechnical Engineering, 8, 39-50.

Amster, K. H. (1988). Unified Soil Classification System Test Procedures. Report Number GR-88-8, Denver, CO: U.S. Department of the Interior, Bureau of Reclamation-Denver Office.

ASTM C136/C136M-19 (2019). Standard Test Method for Sieve Analysis of Fine and Coarse Aggregates. West Conshohocken, PA: ASTM International.

http://www.astm.org

ASTM C702/C702M-18 (2018). Standard Practice for Reducing Samples of Aggregate to Testing Size. West Conshohocken, PA: ASTM International.

http://www.astm.org

ASTM C837-09 (2019). Standard Test Method for Methylene Blue Index of Clay. West Conshohocken, PA: ASTM International. http://www.astm.org

ASTM D1557-12e1 (2012). Standard Test Methods for Laboratory Compaction Characteristics of Soil Using Modified Effort (56,000 ft-lbf/ft3 (2,700 kN-m/m3)). West Conshohocken, PA: ASTM International. http://www.astm.org

ASTM D1883-16 (2016). Standard Test Method for California Bearing Ratio (CBR) of Laboratory-Compacted Soils. West Conshohocken, PA: ASTM International.

http://www.astm.org

ASTM D2216-19 (2019). Standard Test Methods for Laboratory Determination of Water (Moisture) Content of Soil and Rock by Mass. West Conshohocken, PA: ASTM International. www.astm.org

ASTM D2487 (2006). Standard Practice for Classification of Soils for Engineering Purposes. Unified Soil Classification System. West Conshohocken, PA: ASTM International.

ASTM D4318-17e1 (2017). Standard Test Methods for Liquid Limit, Plastic Limit, and Plasticity Index of Soils. West Conshohocken, PA: ASTM International. http://www.astm.org

ASTM D7928-16e1 (2016). Standard Test Method for Particle-Size Distribution (Gradation) of Fine-Grained Soils Using the Sedimentation (Hydrometer) Analysis. West Conshohocken, PA: ASTM International. http://www.astm.org

Ben Abdelghani, F., Maherezi, W., \& Boutouil, M. (2014). Caractérisation géotechnique des sédiments de dragage marins en vue de leur valorisation en techniques routières. Déchets Sciences et Techniques-Nº6-Mars 2014.

Magdi, Z. (2014). Effects of Inadequate Geotechnical Investigation on Civil Engineering Projects. International Journal of Science and Research (IJSR), 3, 927-931.

Mahmoud, H., Belel, Z. A., \& Abba, H. A., (2012). Road Pavement Failure Induced by Poor Soil Properties along Gombi-Biu Highway, Nigeria. Journal of Engineering and Applied Science, 4, 22. 
Masi, E. B., Bicocchi, G., \& Catani, F. (2020). Soil Organic Matter Relationships with the Geotechnical-Hydrological Parameters, Mineralogy and Vegetation Cover of Hillslope Deposits in Tuscany (Italy). Bulletin of Engineering Geology and the Environment, 79, 4005-4020. https://doi.org/10.1007/s10064-020-01819-6

NF ISO 14235 (1998). Qualité du sol-Dosage du carbone organique par oxydation sulfochromique. Paris: AFNOR.

Osuolale, O. M., Oseni, A. A., \& Sanni, I. A. (2012). Investigation of Highway Pavement Failure along Ibadan-Iseyin Road, Oyo State, Nigeria. International Journal of Engineering Research \& Technology, 1, 1-6.

Schaefer, V. R., White, D. J., Ceylan, H., \& Stevens, L. J. (2008). Design Guide for Improved Quality of Roadway Subgrades and Subbases (p. 46). InTrans Project Reports. http://lib.dr.iastate.edu/intrans_reports/46

SETRA-LCPC (1992). Réalisation des remblais et des couches de forms-guide technique. Fascicule I, Principes généraux. Le Laboratoire Central des Ponts et Chaussées. 58, boulevard Lefebvre-F-75732 PARIS CEDEX 15.

Surendra, R., \& Sanjeev, K. B. (2017). Role of Geotechnical Properties of Soil on Civil Engineering Structures. Resources and Environment, 7, 103-109.

Thomas, G. E. (2012). Soil Properties and the Unified Soil Classification System (USCS). PDH Center. 5272 Meadow Estates Drive Fairfax, VA 22030-6658.

USDA (2012). Engineering Classification of Earth Materials. National Engineering Handbook, Part 631, Washington DC: United States Department of Agriculture-Natural Resources Conservation Service, U.S. Government Printing Office.

Utkarsh, M., Nitin, K., Trimurti, N. P., \& Amit, C. (2017). Study of Index Properties of the Soil. IJARIIE-ISSN (O)-2395-4396. 